\title{
AUTOMATION OF ACOUSTIC-EMISSION DIAGNOSTIC SYSTEMS CONTROL PROCESSES
}

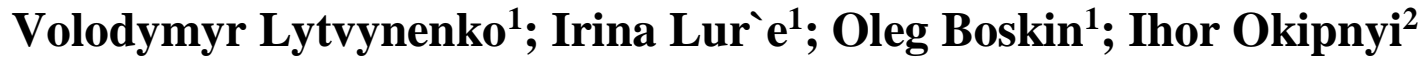

\author{
${ }^{1}$ Kherson National Technical University, Kherson, Ukraine \\ ${ }^{2}$ Ternopil Ivan Puluj National Technical University, Ternopil, Ukraine
}

\begin{abstract}
Summary. The role and place of acoustic emission in the system of technical diagnostics of metal products is determined. The properties of information-measuring systems of acoustic-emission diagnostics are analyzed. It is emphasized on the necessity of solving the main task of acoustic emission systems control - restoration of information on the source of acoustic signals by the measured values of characteristics of acoustic signals at the output. Detailing of information technologies of measurement automation, identification and control is described. Structural diagrams of a priori information of the subject field and characteristics of the components of the acoustic-emission diagnostics hardware are presented. The characteristic features and requirements for the design and operation of individual blocks of the acoustic emission diagnostic system are considered. Algorithms for finding operators in dynamic processes of diagnostics and determining the time of arrival of an acousticemission signal are developed. The stages of automated acoustic emission diagnostics are specified, which are connected with the creation of multichannel systems, the study of the phenomenon of acoustic emission in different deformation conditions, the regularities of changing the acoustic emission signals in the process of damage accumulation. The directions of automation of the processes of control of acoustic-emission systems of technical diagnostics, which are aimed at the detection and indication of acoustic emission signals, their amplification, frequency filtering, discrimination, by determining the threshold level of the registered signals and determining the degree of conformity of the result of diagnostics by the criteria of similarity. The use of automation equipment for the control of acoustic emission systems significantly reduces the time of diagnostic work and saves money spent on their implementation by decommissioning the equipment.
\end{abstract}

Key words: acoustic emission, automation, information parameters, identification, control.

Statement of the problem. The processes of management of acoustic-emission systems is urgent because of the development of measures aimed to create and improve the information technologies for the collection, analysis, processing, and information identification of the received signals in order to increase the reliability of technical diagnostics of metal structures by acoustic emission (AE) methods. The acoustic emission method based on the registration of stress waves occurring as a result of the materials' structure failure, is currently one of the most promising methods for monitoring the state of metal products during their usage. An important advantage of AE diagnostics is the ability to detect defects that develop at the very early stage in order to prevent emergencies. The AE method does not require an external excitation source to obtain material status data and allows to get information about defects at considerable distance from them. The advantage of the AE method is also the ability to predict the state of the controlled object and prevent failures. The reason for the failures is the change of the material's strength due to the natural physical and physico-chemical processes, which is determined by the structure of the material and the operating conditions.

The economic aspect of $\mathrm{AE}$ in technical diagnostics is to reduce maintenance costs. As experience shows, some equipment items get out of order before they undergo routine diagnostic work. At the same time, the rest of the equipment which is in favorable operation conditions arrives for maintenance early. The use of AE method provides additional diagnostic 
information and increases the security and reliability of control while ensuring trouble-free operation of products. Automation of diagnostic control systems with the use of $\mathrm{AE}$ phenomenon is a complicated and poorly researched area which includes automation of circuit solutions and methods of non-destructive control, automation of measurement results processing: algorithms and calculation methods.

The difficulties of implementing AE methods in the system of technical diagnostics consist in separation of useful information from the background noise, instrumental errors, influence of various factors, establishment of cause and effect relationships between changes of structure parameters and measured characteristics of AE signal. The search for informative parameters, development of methods, techniques and means of detecting defects is not only a scientific but a technical task of automation of control processes in systems of technical diagnostics.

Analysis of the available investigations shows that AE diagnostics control systems is connected with the specificity of the solved problems [1-5], methods of registration of useful signals in the conditions of various external disturbances [6-8], search for relationships between the parameters of AE signals and failure processes. The urgent need to develop new methods for monitoring the strength of materials properties is caused by the need to determine the residual life of products and their operational reliability [12-15]. The main problem of diagnostics and monitoring of complex technical systems and objects is the lack of conceptual bases for collecting, processing and analyzing the accumulated information about the state of the object and the data exchange with interconnected automated systems that allow to create approaches for drawing mathematical models in multiparameter state space.

Among the unresolved tasks of the acoustic-emission diagnostic system control processes there are development of algorithms for automation of the assessment of the structures' technical condition and numerical presentation of its results.

Statement of the task. The objective of the work is automation of the AE diagnostic system control by the output signal and to determining the dynamics of the input acoustic signal process.

Due to the fact that the nature of the load in the acoustic emission diagnostics systems is unknown a priori, when establishing the relationship of materials' structure changes with the parameters of the acoustic emission signals, it is necessary to solve the inverse problem of restoring information obtained by the diagnostic system and its identification with the sources of acoustic waves radiation. Solving the tasks of identification and forecasting are necessary to make the right decisions and work out the optimal control.

The problem of restoring information is solved in three main aspects:

- identification - when on the basis of known input and output signals of the system the conclusion about the state of the diagnostic system is made;

- measurement - when the characteristics of the input signal are determined by the known values of the input signal and the characteristics of the diagnostic system;

- control - when the law of the output signal change or the input signal, which at the output brings the system to a predetermined state are determined by the known characteristics of the diagnostic system and the input signal.

Identification of the diagnosed objects' characteristics by input and output signals measurements is one of the main directions of the automated control theory and consists in drawing mathematic model of the object with accuracy by the given criterion in concern to the objectives of automated control processes of acoustic-emission diagnostic systems.

The algorithm for detecting and determining the time of arrival of the AE signal to the registration system consists in comparing the current value of the AE pulse with the dynamic value of the threshold. If the AE signal values exceed the threshold, the signal is considered to be detected and is stored in the computer memory. After the end of a pulse is detected, its 
duration is calculated. Identification of the operator model of the dynamic process of acoustic emission diagnostics involves solving the problem of analyzing the controlled object structure which changes under the influence of operating conditions: alternating loads, high temperatures, pressures, corrosive environments. It should be remembered that acoustic emission is a random process, the automation of which is based on an adequate disturbance response of acoustic emission sources and technical parameters of the diagnostic systems hardware. The description of dynamic systems is related to the use of a specific mathematical model.

A distinctive feature of the acoustic emission diagnostic system is the need to create the model of a dynamic system that will determine the parameters of the AE signals precursor and the material structure characteristics by the output signal. Simulation of the diagnostic system operator allows to solve inverse problems of the set theoretic levels in the state space for linear dynamic systems. During their solving, the prediction tasks require to establish the correspondence of the material states to their changes rate. It should be taken into account that the materials state changes arise before they appear.

Finding the input operator in the dynamic processes of acoustic emission is realized through the inverse task of selecting a model that adequately describes the experimental signal.

Taking into account the stochastic approach to the output signals analysis, the characteristic operator polynomial of recovering information about the material structure that initiates the elastic waves by the signal at the output of the AE of the system $y(t)$ is described by the differential equation of propagation of elastic waves entering the input of the AE of the system:

$$
\frac{d^{m} y(t)}{d t^{m}}+\sum_{m=0}^{m-1} a_{m} \frac{d^{m} y(t)}{d t^{m}}=0
$$

where $l$ - order of differentiation;

$m=0,1,2, \ldots, m-1$ static function of characteristic polynomial.

The solution of this equation is:

$$
y(t)=\sum_{i=1}^{m} C_{i} e^{-r_{i} t} .
$$

Characteristic polynomial of the equation (1) is:

$$
a_{m} r^{m}+a_{m-1} r^{m-1}+\ldots+a_{1} r+a_{0}=0
$$

where $r_{i}$ - solutions of the equation (1).

To estimate the characteristic polynomial $a_{m}$, the residual differences method can be used, where at equal time intervals the average output values of the dynamic range, which is presented be the numerical values of the components of the received signal AE $y_{i}$, are calculated The output range variation is calculated by formula.

$$
\sigma_{0}^{2}=\frac{\sum_{i=1}^{n}\left(y_{i}-\frac{1}{n} \sum_{i=1}^{n} y_{i}\right)^{2}}{n-1} .
$$


After that, by the numerical values of the components of the first differences of the output dynamic range of the received AE signal, the second voltage differences from the diagnosed system output are calculated. Then, the process is repeated for the third, fourth and other differences.

Dispersion of the final K-order range is calculated by formula.

$$
\sigma_{k}^{2}=\frac{\sum_{i=1}^{n-k+1}\left(y_{i}^{(k)}\right)^{2}}{n-k} .
$$

While developing the criteria of the technical condition of objects has there happen the problems of defects classification and their development prediction, and this has to be included in the structure of the algorithm of finding the operator in the dynamic processes of diagnosis.

When solving various problems of analysis and synthesis of the control system, it is necessary to know the characteristics of the control object, so that a properly constructed control signal can translate the control object from its initial state to the necessary one.

A priori information that determines the subject field of the phenomenon under study is always essential in solving the problems of identification. Priority information of the subject field of acoustic emission is presented in Figure 1.

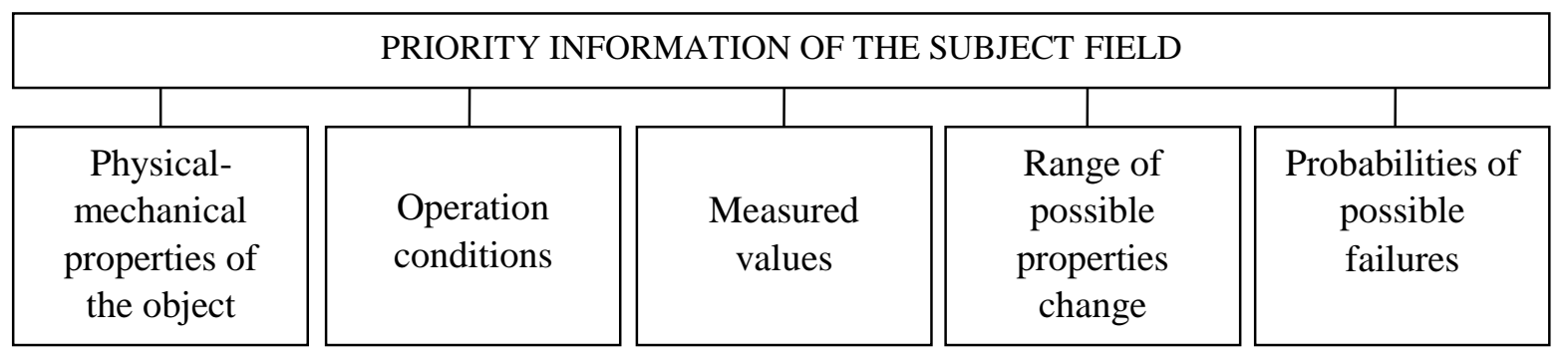

Figure 1. Priority information of the subject field of acoustic emission

The tasks of usage acoustic-emission equipment are:

- receiving of electric signals from AE piezoconverter,

- identification of useful signals from the background noise,

- amplification,

- analogue and digital processing of electric signals,

- evaluation of informative parameters,

- registration,

- providing information,

- documenting of the diagnosis results.

The peculiar feature of acoustic-emission hardware is dependence of energy coming to the AE sensor input on the deformation of the material. Deformation value and its speed increase determine the energy and frequency of elastic vibrations redistricted by with AE meter. Thus, in the acoustic-emission diagnostic systems, studies of spectrum acharacteristics of AE signals are taken as the basis. This causes the necessity of working in a broad dynamic range (up to $100 \mathrm{~dB}$ and more)

The form of the registered pulse depends on the design of the sensors, their locations on the product, as well as on the configuration of the surface and material of the product. Therefore, 
the equipment for receiving AE signal should have a wide range. The occurrence of AE signals is caused by voltage fluctuations in the material structure, which determines the sensitivity requirements of AE sensors. The higher the sensitivity of the AE sensors, the earlier the fault may be detected. The development of defects occurs in the form of amplitude distribution of $\mathrm{AE}$ signals. By setting certain levels of discrimination, it is possible to identify signals that are either noise or development defect. In addition to the inherent noise of AE sensor, the receiving and processing equipment has its own noises, which can be eliminated either by gaskets and cups in the moving parts of loading devices, or by frequency filtration.

The theory of filtration originates from the A.N. Kolmogorov's works on linear estimation of discrete stationary random processes and N. Wiener's researches on continuous random processes. Modern filtering theory is based on the Fourier method, which leads the analyzed signal to the description of the filter in terms of frequency characteristics and decomposition of the spectral plane of the observed process. A new stage in the development of methods for solving the problems of estimation and prediction in the state space in the case of Gaussian processes was obtained with the opening and use of a Kalman filter.

The emergence and solution of filtering problems is due to the fact that not all its characteristics in the control system are represented by accurate deterministic values and the best way to extract information about the studied process is to take it from the measurements of its parameters. This is necessary for making reasoned decisions and for optimal control.

Automated AE diagnostics technology includes:

communication,

- developing multichannel systems with integrated means of network

- study of AE phenomenon under different conditions of deformation,

- search for patterns of signal changes in the process of damage accumulation.

Acoustic emission diagnostics receiving equipment includes a piezoelectric AE sensor, preamplifier, filter unit, main amplifier, discriminator and detector.

Microprocessor technology incorporated into the structure of the diagnostic system is able to solve the problem of control and monitoring the state of strength properties and integrity of the observed objects.

Structural diagram of components and characteristics of the acoustic emission diagnostics equipment is presented in Figure 2.

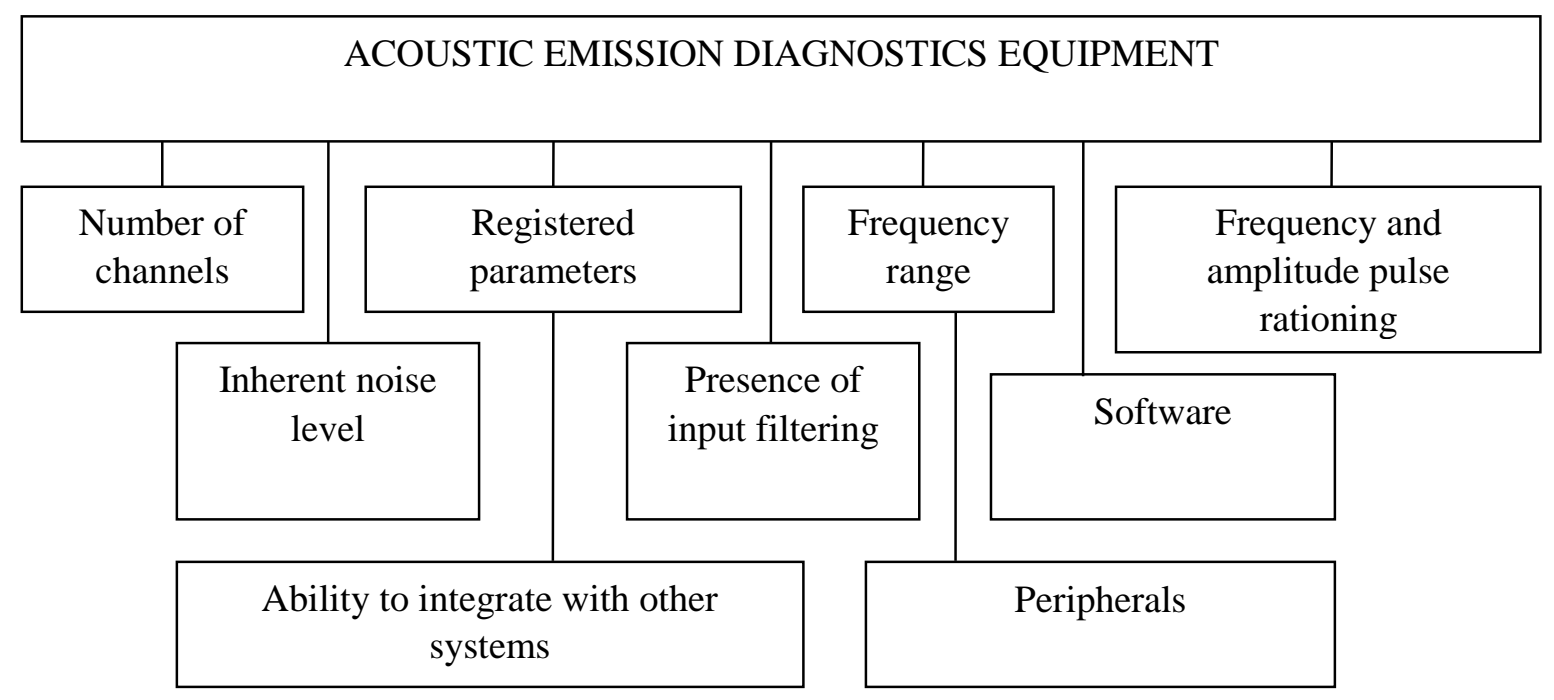

Figure 2. Structural diagram of the characteristics of the equipment of the acoustic emission diagnostics 
The algorithm of control operator simulation in acoustic emission diagnostics systems is presented in Figure 3.

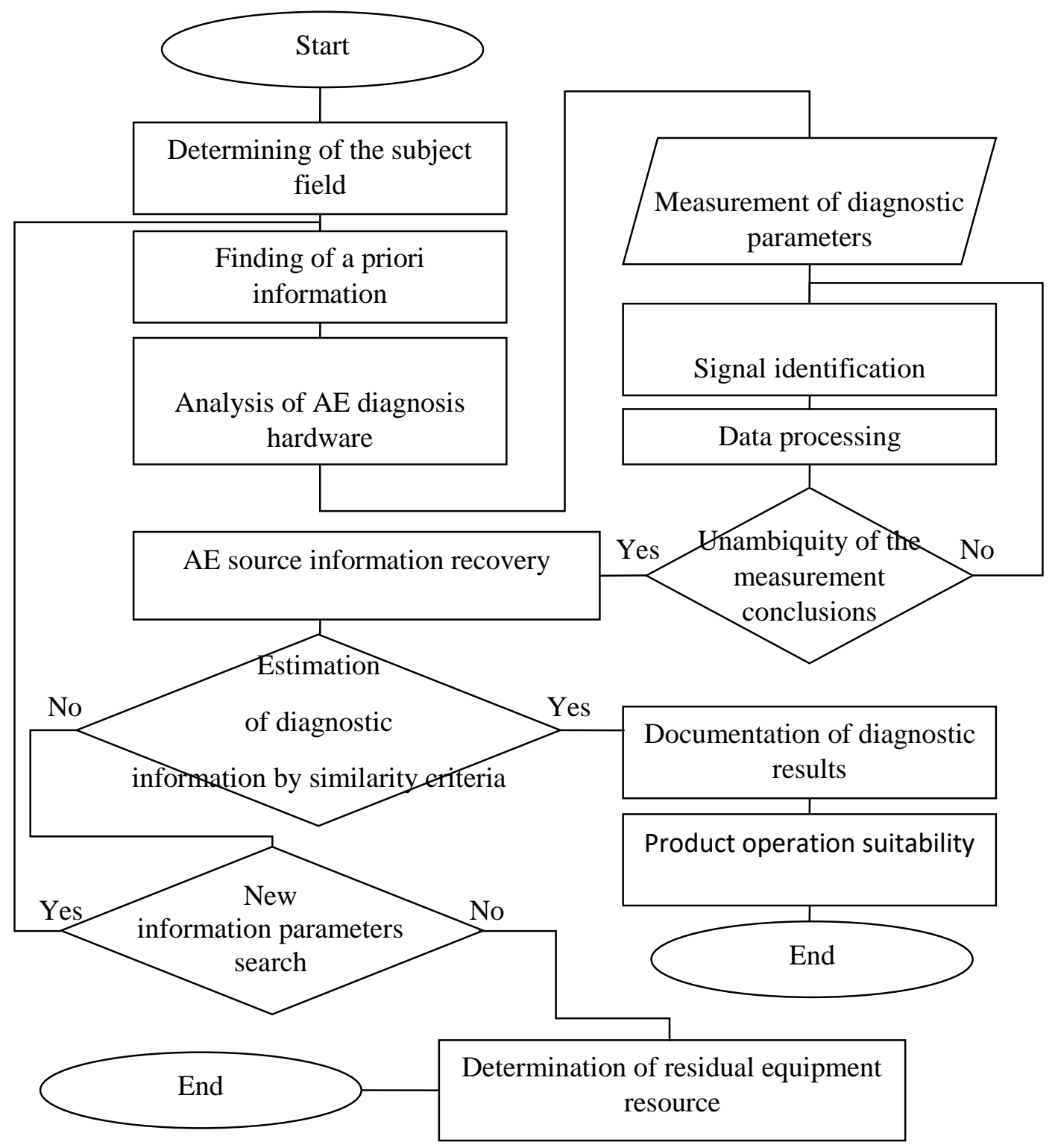

Figure 3. The algorithm of the diagnostic system operator simulation

When using an automated system for monitoring the stress-strain state of structures, a promising direction is the use of integral acoustic-emission parameters of AE signals energy spectrum such as: probability density, signal observation time, amplitude-time distribution, amplitude-frequency distribution, and frequency distribution.

Conclusions. The information-measuring system should provide indication, registration and preprocessing of signals with their further storage in the personal computer memory for further processing of the post of the received data on the temporary delay of the arrival of signals to the sensors from the analysis of mutual correlation function and their visualization in real time. 
The directions of the acoustic emission diagnostics control processes automation should be focused on the detection and indication of AE signals, their amplification, frequency filtering, discrimination by determining the threshold level of the registered signals and establishing the degree of conformity of the diagnostic results with the criteria of similarity.

The analysis of the acoustic-emission signal parameters makes it possible to predict the fracture load and residual equipment life. The method detects the motion of defects, rather than the static inhomogeneities associated with the presence of defects, that is, it detects the developing and therefore the most dangerous defects. The connection between the processes of defect formation and the presence of acoustic signals allows to determine the degree of the material efficiency. This determines the special role of the acoustic emission method in the technical diagnostics of metal products. The use of automation equipment for the acoustic emission systems control significantly reduces the time of diagnostic work and saves money spent on their maintenance by decommissioning the equipment.

\section{References}

1. Marasanov V. V., Sharko A. V., Kobersky V. V., Sharko A. A. Informative parameters and acoustic emission control schemes. Problems of information technology. 2016. No. 01 (019). P. 182-191.

2. Papirov I. I., Stoev P. I. Detection and study of acoustic emission effects during plastic deformation of steels in a magnetic field. Dopovidi National Academy of Sciences of Ukraine. 2014. No. 1. P. 81-89. https://doi.org/10.15407/dopovidi2014.01.081

3. Nedoseka A. Ya., Nedoseka S. A., Markasheva L. I., Kushnareva U. S. On the recognition of changes in the structure of materials during destruction according to acoustic emission data. Technical diagnostics and non-destructive testing. 2016. No. 4. P. 9-13. https://doi.org/10.15407/tdnk2016.04.02

4. Pochapskyy Y., Klym B., Melnyk N. Mathematical model and informative parameters of the magnetoelastic acoustic emission signal. Scientific Journal of TNTU. 2019. Vol. 94.No. 2. P. 37-50. https://doi.org/10.33108/visnyk_tntu2019.02.037

5. Luchko J., Ivanyk E. Diagnostics of the main gas pipelines and assessment of their residual life under the conditions of long-term operation. Scientific Journal of TNTU. 2017. Vol. 87. No. 3. P. 48-63. https://doi.org/10.33108/visnyk_tntu2017.03.048

6. Ivanov V. I., Barat V. A. Acoustic emission diagnostics: reference book. M.: Publishing house «Spectrum», 2017. 368 p.

7. Li H., Wang W., Huang P., Li Q. Fault diagnosis of rolling bearing using symmetrized dot pattern and density-based clustering. Measurement: Journal of the International Measurement Confederation. 2020. № 107293. P. 152. https://doi.org/10.1016/j.measurement.2019.107293

8. Gnevko A., Zubov O., Graizon S., Mukomelo M., and Kobzev V. Assessment of the technical condition of objects operating under pressure with limited access to the surface using the acoustic emission method. Scientific Bulletin of MGTU GA. 2015. № 2017. P. 9-16. [In Russian].

9. Zhao X., Jia M., Lin M. Deep Laplacian Auto-encoder and its application into imbalanced fault diagnosis of rotating machinery. Measurement: Journal of the International Measurement Confederation. 2020. № 107320. P. 152. https://doi.org/10.1016/j.measurement.2019.107320

10. Surace C., Bovsunovsky A. The use of frequency ratios to diagnose structural damage in varying environmental conditions. Mechanical Systems and Signal Processing. 2020. № 106523. P. 136. https://doi.org/10.1016/j.ymssp.2019.106523

11. Paton B., Lobanov L., Nedosek A., Nedosek S., Gurzd A., Yaremenko M. Experience of IEE Paton NAS of Ukraine in the field of acoustic emission control. Technical diagnostics and non-destructive control. 2012. № 1. P. 7-22. [In Russian].

12. Devin L., Rychev S., Correlation model of acoustic emission at fine diamond turning. Superhard materials. 2017. № 1. P. 56-65. [In Russian]. https://doi.org/10.3103/S1063457617010051

13. Kuzmin A., Automation of engineering and technical diagnostics of high-rise buildings on the basis of complexing of methods and means of non-destructive control. Technospheric safety technology. 2008. № 5. P. 7-12. [In Russian].

14. Ovcharuk V., Pursiev Yu. Registration and processing of acoustic emission information in multichannel systems. Khabarovsk from the Pacific State University. 2016. P. 116. [In Russian].

15. Luzina N. Analysis of the result of control of technical products by the method of acoustic emission. Scientific Bulletin of St. Petersburg State University. 2011. № 3 (73). P. 78-84. [In Russian]. 


\title{
Список використаної літератури
}

1. Marasanov V. V., Sharko A. V., Kobersky V. V., Sharko A. A. Informative parameters and acoustic emission control schemes. Problems of information technology. 2016. No. 01 (019). P. 182-191.

2. Papirov I. I., Stoev P. I. Detection and study of acoustic emission effects during plastic deformation of steels in a magnetic field. Dopovidi National Academy of Sciences of Ukraine. 2014. No. 1. P. 81-89. https://doi.org/10.15407/dopovidi2014.01.081

3. Nedoseka A. Ya., Nedoseka S. A., Markasheva L. I., Kushnareva U. S. On the recognition of changes in the structure of materials during destruction according to acoustic emission data. Technical diagnostics and non-destructive testing. 2016. No. 4. P. 9-13. https://doi.org/10.15407/tdnk2016.04.02

4. Pochapskyy Y., Klym B., Melnyk N. Mathematical model and informative parameters of the magnetoelastic acoustic emission signal. Scientific Journal of TNTU. 2019. Vol. 94.No. 2. P. 37-50. https://doi.org/10.33108/visnyk_tntu2019.02.037

5. Luchko J., Ivanyk E. Diagnostics of the main gas pipelines and assessment of their residual life under the conditions of long-term operation. Scientific Journal of TNTU. 2017. Vol. 87. No. 3. P. 48-63. https://doi.org/10.33108/visnyk_tntu2017.03.048

6. Ivanov V. I., Barat V. A. Acoustic emission diagnostics: reference book. M.: Publishing house «Spectrum», 2017. 368 p.

7. Li H., Wang W., Huang P., Li Q. Fault diagnosis of rolling bearing using symmetrized dot pattern and density-based clustering. Measurement: Journal of the International Measurement Confederation. 2020. № 107293. P. 152. https://doi.org/10.1016/j.measurement.2019.107293

8. Гневко А. И., Зубов О. Е., Граизон С. В., Мукомело М. В., Кобзев В. А. Оценка технического состояния объектов работающие под давлением при ограниченном доступе к поверхности с использованием метода акустической эмиссии. Научный вестник МГТУ ГА. 2015. № 2017. C. 9-16.

9. Zhao X., Jia M., Lin M. Deep Laplacian Auto-encoder and its application into imbalanced fault diagnosis of rotating machinery. Measurement: Journal of the International Measurement Confederation. 2020. № 107320. P. 152. https://doi.org/10.1016/j.measurement.2019.107320

10. Surace C., Bovsunovsky A. The use of frequency ratios to diagnose structural damage in varying environmental conditions. Mechanical Systems and Signal Processing. 2020. № 106523. P. 136. https://doi.org/10.1016/j.ymssp.2019.106523

11. Патон Б. Е., Лобанов Л. М., Недосека А. Я., Недосека С. А., Гурзд А. А., Яременко М. А. Опыт ИЭС им. Е. О. Патона НАН Украины в области акустико-эмиссионного контроля. Техническая диагностика и неразрушающий контроль. 2012. № 1. С. 7-22.

12. Девин Л. Н., Рычев С. В., Корреляционная модель акустической эмиссии при тонком алмазном точении. Сверхтвёрдые материалы. 2017. № 1. С. 56-65. https://doi.org/10.3103/S1063457617010051

13. Кузмин А. А., Автоматизация инженерно-технической диагностики высотных зданий на основе комплексирования методов и средств неразрушающего контроля. Технология техносферной безопасности. 2008. № 5. С. 7-12.

14. Овчарук В. Н., Пурсиев Ю. А. Регистрация и обработка акустико-эмиссионной информации в многоканальных системах. Хабаровск: из-во Тихоокеанского государственного университета, 2016. $116 \mathrm{c}$.

15. Лузина Н. П. Анализ результата контроля технических изделий методом акустической эмиссии. Научный вестник Санкт-Петербургского государственного университета. 2011. № 3 (73). С. $78-84$.

\section{УДК 667.64:678.02}

\section{АВТОМАТИЗАЦІЯ ПРОЦЕСІВ УПРАВЛІННЯ АКУСТИКО- ЕМІСІЙНИМИ ДІАГНОСТИЧНИМИ СИСТЕМАМИ}

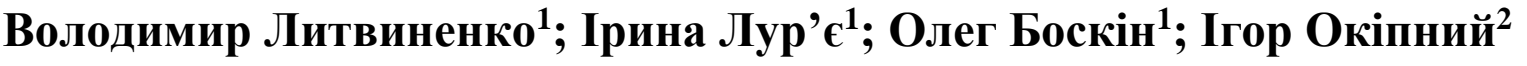 \\ ${ }^{1}$ Херсонський національний технічний університет, Херсон, Украйна \\ ${ }^{2}$ Тернопільський національний технічний університет імені Івана Пулюя, \\ Тернопіль, Украӥна
}

\footnotetext{
Резюме. Визначено роль $i$ місие акустичної емісії в системі технічної діагностики металопродукиї. Наводиться аналіз властивостей інформаційно-вимірювальних систем акустико-
} 
емісійної діагностики. Наголошено на необхідності вирішення основного завдання управління системами акустико-емісійної діагностики - відновлення інформації про джерело акустичних сигналів по виміряним значенням характеристик акустичних сигналів на виході. Описана деталізація інформаційних технологій автоматизації вимірювань, ідентифікації та управління. Представлені структурні схеми апріорної інформації предметного поля і характеристик компонентів апаратурної частини акустико-емісійної діагностики. Розглянуто характерні особливості та вимоги до конструювання та функиіонування окремих блоків акустико-емісійної системи діагностування. Розроблено алгоритми знаходження операторів у динамічних процесах діагностики та визначення моментів часу приходу акустико-емісійного сигналу. Конкретизовано етапи автоматизованої акустико-емісійної діагностики які пов'язані зі створенням багатоканальних систем, вивченням явища акустичної емісії в різних умовах деформування, закономірностей зміни сигналів акустичної емісії в процесі накопичення пошкоджень. Вказані напрямки автоматизачї прочесів управління акустико-емісійними системами технічного діагностування, які спрямовані на виявлення та індикацію сигналів акустичної емісії, їх посилення, частотну фільтрацію, дискримінацію, иляхом визначення порогового рівня реєстрованих сигналів $i$ визначення ступеня відповідності результатом діагностики за критеріями подібності. Використання апаратного забезпечення автоматизачії управління акустико-емісійними системами значно скорочує час проведення діагностичних робіт і економить кошти, які витрачаються на їх впровадження за рахунок виведення обладнання з експлуатаиіiі.

Ключові слова: акустична емісія, автоматизачія, інформачійні параметри, ідентифікаџія, управління. 